\title{
PENGARUH PENAMBAHAN WORTEL (Daucus carota) PADA PEMBUATAN CUKA APEL TERHADAP KUALITAS MINUMAN HASIL FERMENTASI
}

\author{
Effect of Addition of Carrot (Daucus carota) in Making Vinegar to Quality of Drinking \\ Fermentation Result
}

\author{
A. Zainul Arifin ${ }^{1)}$ dan Sri Hariningsih Pratiwi ${ }^{1}$ \\ ${ }^{1)}$ Dosen Universitas Merdeka Pasuruan \\ email : ahmadunmer23@yahoo.com
}

\begin{abstract}
Apples and carrots are fruits that provide favorable results and are often used as functional beverages. One of the functional drinks made from apples is apple vinegar. The purpose of this research is to know the proper giving of carrot extract in the process of making apple vinegar to produce a quality beverage product. This experiment uses a single factor completely Randomized Design. Data were analyzed using variance analysis with 5\% BNT test. The results showed that the best combination of treatment parameters was obtained from a combination of $5 \mathrm{~kg}$ of apple fermentation treatment plus $2.5 \mathrm{~kg}$ extract of carrot extract after stage 2 process with alcohol or ethanol content of $2.52 \%$, total acid of $24.36 \%$, reducing sugar by $7,80 \%$, vitamin A equal to 136,6 Si / $100 \mathrm{ml}$, and vitamin C equal to 2,62 $\mathrm{mg} / 100 \mathrm{ml}$.
\end{abstract}

Keywords: apple, carrot, vinegar

\begin{abstract}
ABSTRAK
Apel dan wortel merupakan buah yang memberikan hasil yang menguntungkan dan sering dijadikan sebagai bahan baku minuman fungsional. Salah satu minuman fungsional berbahan apel adalah cuka apel. Tujuan dari penelitian ini adalah untuk mengetahui pemberian ekstrak wortel yang tepat pada proses pembuatan cuka apel untuk menghasilkan produk minuman yang berkualitas. Percobaan ini menggunakan Rancangan Acak Lengkap faktor tunggal. Data dianalisis mengunakan analisis ragam dengan uji BNT 5\%. Hasil penelitian menunjukkan bahwa kombinasi perlakuan terbaik pada parameter kmia didapatkan dari kombinasi perlakuan fermentasi apel $5 \mathrm{~kg}$ ditambah ekstrak sari wortel $2,5 \mathrm{~kg}$ setelah proses tahap 2 dengan kadar alkohol atau etanol sebesar 2,52\%, total asam sebesar $24,36 \%$, kadar gula reduksi sebesar 7,80\%, vitamin A sebesar 136,6 Si/100 ml, dan vitamin C sebesar 2,62 mg/100 ml
\end{abstract}

Kata kunci: apel, wortel, cuka

\section{PENDAHULUAN}

Apel adalan buah yang memberikan hasil yang menguntungkan, tumbuh pada suhu sedang. Fruktosa, glukosa dan sukrosa merupakan tiga jenis gula utama yang ditemukan pada apel dan kadarnya beragam dengan adanya tingkat perkembangan, iklim dan cara penanaman buah (Kaushal dan Sharman, 1995). Apel memiliki peranan sangat penting ditinjau dari kandungan zatzat gizinya terutama vitamin, mineral dan proteinnya. Salunkhe (1991), asam-asam amino penyusun protein yang terdapat di dalam buah apel adalah leusin, solensin, valin, fenilanin, triptofan, asam glutamat, histidin, arginin, treonin, netionin, lisin, asam aspartat, serin, glisin, prolin, sistein dan asparagin. Hlebowicz et al. (2007), buah apel dapat digunakan sebagai obat alternative untuk menyembuhkan penyakit diabetes, 
Wortel (Daucus carota L.) merupakan tanaman yang mempunyai manfaat kesehatan yang pada manusia, karena sebagi sumber karotenoid provitamin A (Grune et al., 2010; Bowman dan Simon, 2013) dan sumber $\beta$-karoten alami (Lorenz, 2000 dalam Woro et al., 2009). Karoten dalam wortel juga dapat mencegah penyakit rabun senja (Rukmana, 1995) dan dapat digunakan untuk menurunkan berat badan atau diet (Arscott dan Tanumihardjo, 2010; MechNowak et al., 2012).

Pengembangan lebih lanjut menjadi produk pangan (minuman) komersial memerlukan penelitian mendalam untuk memperoleh data yang pasti mengenai metode tradisional yang jarang dipakai pada kalangan industri minuman. Keunggulan yang paling penting adalah bahwa produk tersebut harus aman dan klaim manfaatnya nyata. Minuman asam adalah proses yang dilakukan terhadap bahan (buah-buahan) dengan cara difermentasi melalui dua tahap, yaitu tahap 1 fermentasi anaerob dan tahap 2 fermentasi aerob dengan mikroorganisme Saccharomyces cerevisiae. Larutan yang dihasilkan dari proses tersebut diatas dikenal dengan sebutan cuka, sebagai contoh jika bahan baku dari buah apel seringkali hasilnya disebut sebagai cuka apel (Wibowo, 1990).

Cuka apel merupakan salah satu jenis bahan baku yang dapat dijadikan sebagai minuman fungsional karena mengandung karotenoid (sumber vitamin A) dan merupakan antioksidan sehingga dapat menangkis serangan radikal-radikal bebas yang dapat merusak tubuh (Wijayakusuma, 2000).

\section{BAHAN DAN METODE}

\section{Bahan}

Bahan yang digunakan dalam penelitian ini adalah buah apel dan wortel, Gula 500 gram, dekstrosa 100 gram, dan Natural yeast komersial (Saccharomyces cerevisiae) 25 gram yang diperoleh di daerah Kabupaten Pasuruan.
Alat

Alat-alat yang digunakan dalam analisis berupa timbangan digital, panci steanless steel, (XP-1500, Jerman), vortex (Barnstead), tabung reaksi (Pyrex), gelas ukur $50 \mathrm{ml}$ (Pyrex), erlenmeyer $250 \mathrm{ml}$ (Pyrex), labu ukur $100 \mathrm{ml}$ (Pyrex), pipet mikro10-100 $\mu$ l (Soccorex), pipet volum 1 $\mathrm{ml}$ (Assistance), pipet volum $5 \mathrm{ml}$ (HBG), beaker glass $250 \mathrm{ml}$ (Pyrex), corong pemisah $100 \mathrm{ml}$ (Schott-Duran), rak kayu tabung reaksi.

\section{Rancangan Penelitian}

Rancangan yang digunakan dalam penelitian ini menggunakan Rancangana Acak Faktorial faktor tunggal dengan dengan 4 (empat) level perbandingan bahan apel dan wortel yaitu : P1 = fermentasi apel $5 \mathrm{~kg}$ tanpa wortel (kontrol); P2 = fermentasi apel $5 \mathrm{~kg}$ dan wortel $2,5 \mathrm{~kg}$ (diblender bersama); $\mathrm{P} 3=$ fermentasi apel $5 \mathrm{~kg}$ ditambah ekstrak sari wortel $2,5 \mathrm{~kg}$ setelah proses tahap 1; dan $\mathrm{P} 4=$ fermentasi apel 5 $\mathrm{kg}$ ditambah ekstrak sari wortel $2,5 \mathrm{~kg}$ setelah proses tahap 2 .

Masing-masing level diulang sebanyak tujuh kali sehingga dihasilkan 28 satuan percobaan. Perlakuan yang memiliki indeks efektifitas berdasarkan paramater uji organoleptik (warna, rasa dan aroma) dan uji kimia (kadar alkohol, total asam, kadar gula reduksi dan kandungan vitamin) terbaik dari perlakuan diatas yang dinilai layak secara teknis.

\section{Pengamatan}

Pengamatan dilakukan terhadap produk akhir minuman hasil fermentasi cuka apel wortel meliputi uji organoleptik (warna, rasa dan aroma) dari 30 responden.

\section{Analisis Data}

Data hasil parameter dianalisis dengan analisis sidik ragam dengan uji BNT 5\%. 


\section{HASIL DAN PEMBAHASAN}

\section{Kadar Alkohol}

Rerata kadar alkohol pada berbagai kombinasi perlakuan antara perlakuan fermentasi cuka apel dengan tambahan wortel terhadap kadar alkohol berkisar antara $2-2,74 \%$. Hasil analisis sidik ragam memperlihatkan bahwa adanya perbedaan antara fermentasi cuka apel dengan tambahan wortel, serta interaksi antar perlakuan memberikan pengaruh sangat nyata pada uji BNT 5\% terhadap kadar alkohol. Rerata nilai kadar alkohol pada berbagai kombinasi perlakuan diperlihatkan pada Tabel 1.

Tabel 1. Rerata kadar alkohol (\%)

\begin{tabular}{|c|c|c|}
\hline Kombinasi perlakuan & $\begin{array}{l}\text { Rerata } \\
\text { kadar } \\
\text { alkohol } \\
(\%)\end{array}$ & $\begin{array}{c}\text { BNT } \\
(\alpha=0,05)\end{array}$ \\
\hline $\begin{array}{l}\text { Fermentasi apel } 5 \mathrm{~kg} \text { tanpa } \\
\text { wortel (kontrol) (P1) }\end{array}$ & $2 \mathrm{a}$ & \multirow{4}{*}{0,0407} \\
\hline $\begin{array}{l}\text { Fermentasi apel } 5 \mathrm{~kg} \text { dan } \\
\text { wortel } 2,5 \mathrm{~kg} \text { (diblender } \\
\text { bersama) }(\mathrm{P} 2)\end{array}$ & $2,16 b$ & \\
\hline $\begin{array}{l}\text { Fermentasi apel } 5 \quad \mathrm{~kg} \\
\text { ditambah ekstrak } \\
\text { wortel } 2,5 \mathrm{~kg} \text { sari } \\
\text { proses tahap } 1(\mathrm{P} 3)\end{array}$ & $2,74 d$ & \\
\hline $\begin{array}{l}\text { Fermentasi apel } 5 \text { kg } \\
\text { ditambah ekstrak sari } \\
\text { wortel 2,5 } \mathrm{kg} \text { setelah } \\
\text { proses tahap } 2(\mathrm{P} 4)\end{array}$ & $2,52 \mathrm{c}$ & \\
\hline 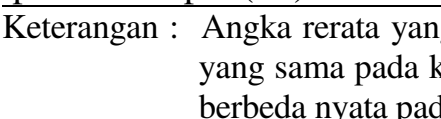 & 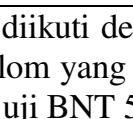 & \\
\hline
\end{tabular}

Tabel 1. memperlihatkan uji BNT $(\alpha=$ $0,05)$ kombinasi perlakuan terbaik kadar alkohol yang diperoleh dari fermentasi apel $5 \mathrm{~kg}$ ditambah ekstrak sari wortel $2,5 \mathrm{~kg}$ setelah proses tahap 1 (P3) sebesar 2,74\% dan sangat berbeda nyata dengan yang lain. Grafik rerata kadar alkohol pada berbagai kombinasi perlakuan antara fermentasi cuka apel dengan tambahan wortel diperlihatkan pada Gambar 1.

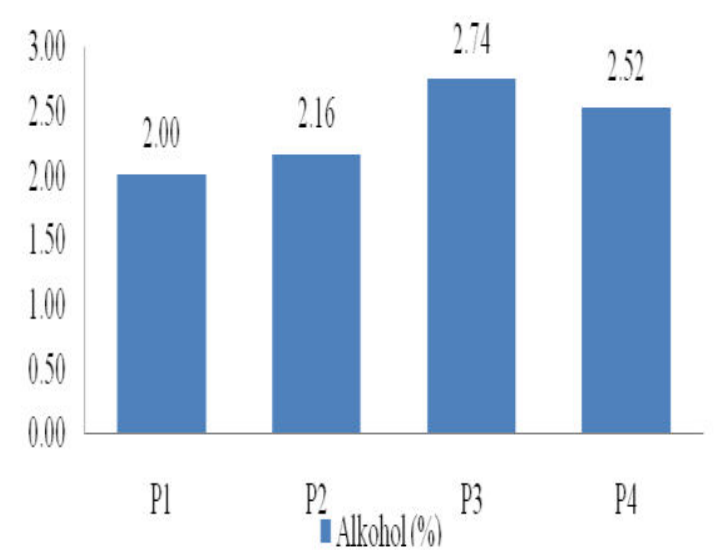

Gambar 1. Grafik kadar alkohol (\%)

Gambar 1 memperlihatkan bahwa kadar alkohol tertinggi diperoleh pada kombinasi perlakuan fermentasi apel $5 \mathrm{~kg}$ ditambah ekstrak sari wortel $2,5 \mathrm{~kg}$ setelah proses tahap 1 (P3) sebesar 2,74\% dan terendah pada fermentasi apel $5 \mathrm{~kg}$ tanpa wortel (kontrol) (P1) sebesar 2\%.

\section{Kadar Total Asam}

Rerata kadar total asam pada berbagai kombinasi perlakuan antara perlakuan fermentasi cuka apel dengan tambahan wortel terhadap kadar total asam berkisar antara 11,30-24,36\%). Hasil analisis sidik ragam memperlihatkan bahwa adanya perbedaan antara fermentasi cuka apel dengan tambahan wortel, serta interaksi antar perlakuan memberikan pengaruh sangat nyata pada uji BNT 5\% terhadap kadar total asam. Rerata nilai kadar total asam pada berbagai kombinasi perlakuan diperlihatkan pada Tabel 2 .

Tabel 2 memperlihatkan uji BNT $(\alpha=$ $0,05)$ kombinasi perlakuan terbaik kadar total asam yang diperoleh dari fermentasi apel $5 \mathrm{~kg}$ ditambah ekstrak sari wortel 2,5 $\mathrm{kg}$ setelah proses tahap 2 (P4) sebesar $24,36 \%$ dan sangat berbeda nyata dengan yang lain. Grafik rerata kadar total asam pada berbagai kombinasi perlakuan antara fermentasi cuka apel dengan tambahan wortel diperlihatkan pada Gambar 2. 
Tabel 2. Kadar total asam (\%)

\begin{tabular}{lll}
\hline \multicolumn{1}{c}{ Kombinasi perlakuan } & $\begin{array}{c}\text { Rerata } \\
\text { kadar total } \\
\text { asam }(\%)\end{array}$ & $\begin{array}{c}\text { BNT } \\
(\alpha=0,05\end{array}$ \\
\hline $\begin{array}{l}\text { Fermentasi apel } 5 \mathrm{~kg} \text { tanpa } \\
\text { wortel (kontrol) }(\mathrm{P} 1)\end{array}$ & $11,30 \mathrm{a}$ & \\
$\begin{array}{l}\text { Fermentasi apel } 5 \mathrm{~kg} \text { dan } \\
\text { wortel } 2,5 \mathrm{~kg}(\text { diblender } \\
\text { bersama })(\mathrm{P} 2)\end{array}$ & $16,44 \mathrm{~b}$ & \\
$\begin{array}{l}\text { Fermentasi apel } 5 \mathrm{~kg} \\
\text { ditambah ekstrak sari }\end{array}$ & & \\
$\begin{array}{l}\text { wortel 2,5 kg setelah proses } \\
\text { tahap 1 (P3) }\end{array}$ & $20,36 \mathrm{c}$ & 0,0407 \\
$\begin{array}{l}\text { Fermentasi apel } 5 \mathrm{~kg} \\
\text { ditambah ekstrak sari } \\
\text { wortel 2,5 kg setelah proses } \\
\text { tahap 2 (P4) }\end{array}$ & $24,36 \mathrm{~d}$ \\
\hline $\begin{array}{l}\text { Keterangan : Angka rerata yang diikuti dengan huruf } \\
\text { yang sama pada kolom yang sama tidak berbeda nyata }\end{array}$ \\
pada uji BNT 5\%
\end{tabular}

Gambar 2 memperlihatkan bahwa kadar total asam tertinggi diperoleh pada kombinasi perlakuan fermentasi apel $5 \mathrm{~kg}$ ditambah ekstrak sari wortel $2,5 \mathrm{~kg}$ setelah proses tahap 1 (P3) sebesar 24,36\% dan terendah pada fermentasi apel $5 \mathrm{~kg}$ tanpa wortel (kontrol) (P1) sebesar 11,3\%.

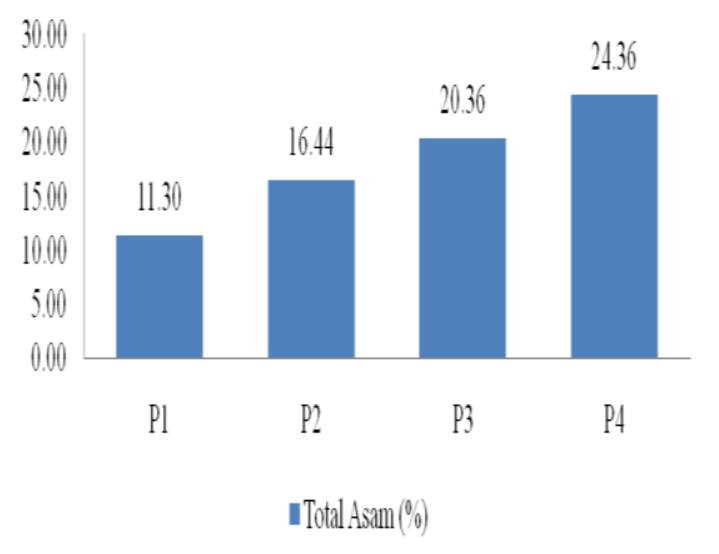

Gambar 2. Grafik kadar total asam (\%)

\section{Kadar Gula Reduksi}

Rerata kadar gula reduksi pada berbagai kombinasi perlakuan antara perlakuan fermentasi cuka apel dengan tambahan wortel terhadap kadar gula reduksi berkisar antara 5,47-7,8\%. Hasil analisis sidik ragam memperlihatkan bahwa adanya perbedaan antara fermentasi cuka apel dengan tambahan wortel, serta interaksi antar perlakuan memberikan pengaruh sangat nyata pada uji BNT 5\% terhadap kadar gula reduksi. Rerata nilai kadar gula reduksi pada berbagai kombinasi perlakuan diperlihatkan pada Tabel 3.

Tabel 3. Kadar gula reduksi (\%)

\begin{tabular}{ccc}
\multicolumn{3}{c}{ Tabel 3. Kadar gula reduksi $(\%)$} \\
& Rerata & \\
& kadar & BNT \\
Kombinasi perlakuan & gula & $(\alpha=0,05)$ \\
& reduksi \\
& $(\%)$ & \\
\hline
\end{tabular}

Fermentasi apel $5 \mathrm{~kg}$ tanpa $\quad 5,47$

wortel (kontrol) (P1)

Fermentasi apel $5 \mathrm{~kg}$ dan

wortel $2,5 \mathrm{~kg}$ (diblender $\quad 6,19$

bersama) (P2)

Fermentasi apel $5 \mathrm{~kg}$

ditambah ekstrak sari

wortel $2,5 \mathrm{~kg}$ setelah proses

6,78

0,0407

tahap 1 (P3)

Fermentasi apel $5 \mathrm{~kg}$

ditambah ekstrak sari

wortel $2,5 \mathrm{~kg}$ setelah proses

7,80

tahap 2 (P4)

Keterangan : Angka rerata yang diikuti dengan huruf
yang sama pada kolom yang sama
tidak berbeda nyata pada uji BNT 5\%

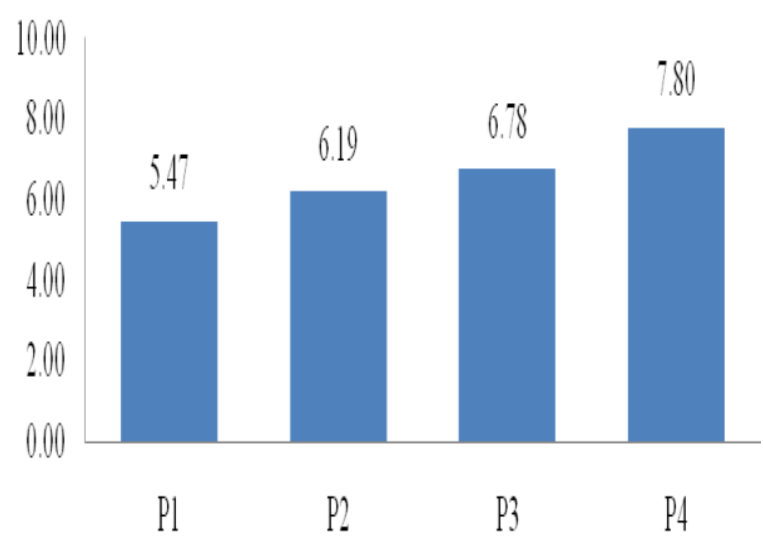

\section{-Gulla Redulksil $(\%)$}

Gambar 3. Grafik kadar gula reduksi (\%)

Tabel 3 memperlihatkan uji BNT $(\alpha=$ $0,05)$ kombinasi perlakuan terbaik kadar gula reduksi yang diperoleh dari fermentasi apel $5 \mathrm{~kg}$ ditambah ekstrak sari wortel 2,5 $\mathrm{kg}$ setelah proses tahap 2 (P4) sebesar 7,8\% dan sangat berbeda nyata dengan yang lain. Grafik rerata kadar gula reduksi pada 
berbagai kombinasi perlakuan antara fermentasi cuka apel dengan tambahan wortel diperlihatkan pada Gambar 3.

Gambar 3 memperlihatkan bahwa kadar gula reduksi tertinggi diperoleh pada kombinasi perlakuan fermentasi apel $5 \mathrm{~kg}$ ditambah ekstrak sari wortel $2,5 \mathrm{~kg}$ setelah proses tahap 1 (P3) sebesar 5,47\% dan terendah pada fermentasi apel $5 \mathrm{~kg}$ tanpa wortel (kontrol) (P1) sebesar 7,8\%.

\section{Kadar Vitamin A}

Rerata kadar Vitamin A pada berbagai kombinasi perlakuan antara perlakuan fermentasi cuka apel dengan tambahan wortel terhadap kadar Vitamin A berkisar antara 90,63-136,6 SI/100 ml. Hasil analisis sidik ragam memperlihatkan bahwa adanya perbedaan antara fermentasi cuka apel dengan tambahan wortel, serta interaksi antar perlakuan memberikan pengaruh sangat nyata pada uji BNT 5\% terhadap kadar Vitamin A. Rerata nilai kadar Vitamin A pada berbagai kombinasi perlakuan diperlihatkan pada Tabel 4.

Tabel 4. Kadar Vitamin A (SI/ $100 \mathrm{ml})$

$\begin{array}{ccc} & \text { Rerata } & \\ & \text { kadar } & \\ \text { Kombinasi perlakuan } & \text { Vitamin A } & \text { BNT } \\ & (\mathrm{SI} / 100 & (\alpha=0,05) \\ & \mathrm{ml}) & \end{array}$

\begin{tabular}{l}
\hline Fermentasi apel $5 \mathrm{~kg}$ tanpa \\
wortel (kontrol) $(\mathrm{P} 1)$ \\
Fermentasi apel $5 \mathrm{~kg}$ dan
\end{tabular}
wortel 2,5 $\mathrm{kg}$ (diblender

114,51 bersama) (P2)

Fermentasi apel $5 \mathrm{~kg}$ ditambah ekstrak sari wortel 2,5 $\mathrm{kg}$ setelah proses tahap 1 (P3)

Fermentasi apel $5 \mathrm{~kg}$ ditambah ekstrak sari wortel 2,5 $\mathrm{kg}$ setelah proses tahap 2 (P4)

Keterangan : Angka rerata yang diikuti dengan huruf yang sama pada kolom yang sama tidak berbeda nyata pada uji BNT 5\%

Tabel 4 memperlihatkan uji BNT $(\alpha=$ $0,05)$ kombinasi perlakuan terbaik kadar Vitamin A yang diperoleh dari fermentasi apel $5 \mathrm{~kg}$ ditambah ekstrak sari wortel 2,5 $\mathrm{kg}$ setelah proses tahap 2 (P4) sebesar 136,6 $\mathrm{SI} / 100 \mathrm{ml}$ dan sangat berbeda nyata dengan yang lain. Grafik rerata kadar Vitamin A pada berbagai kombinasi perlakuan antara fermentasi cuka apel dengan tambahan wortel diperlihatkan pada Gambar 4.

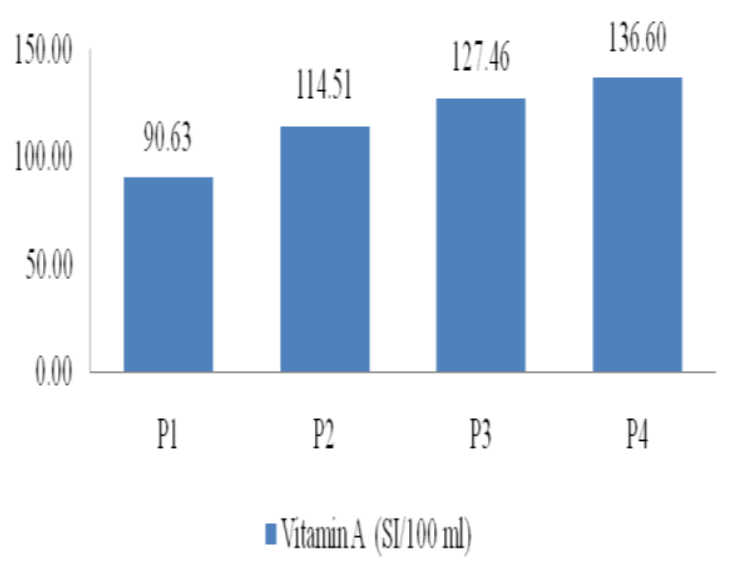

Gambar 4. Grafik kadar Vitamin A (SI/ $100 \mathrm{ml})$

Gambar 4 memperlihatkan bahwa kadar Vitamin A tertinggi diperoleh pada kombinasi perlakuan fermentasi apel $5 \mathrm{~kg}$ ditambah ekstrak sari wortel $2,5 \mathrm{~kg}$ setelah proses tahap 1 (P3) sebesar 90,63 SI/100 ml dan terendah pada fermentasi apel $5 \mathrm{~kg}$ tanpa wortel (kontrol) (P1) sebesar 136,6 $\mathrm{SI} / 100 \mathrm{ml}$.

\section{Kadar Vitamin C}

Rerata kadar Vitamin C pada berbagai kombinasi perlakuan antara perlakuan fermentasi cuka apel dengan tambahan wortel terhadap kadar Vitamin C berkisar antara 2,37-4,05 mg/100 ml. Hasil analisis sidik ragam memperlihatkan bahwa adanya perbedaan antara fermentasi cuka apel dengan tambahan wortel, serta interaksi antar perlakuan memberikan pengaruh sangat nyata pada uji BNT 5\% terhadap kadar Vitamin C. Rerata nilai kadar Vitamin C pada berbagai kombinasi perlakuan diperlihatkan pada Tabel 5.

Tabel 5 memperlihatkan uji BNT ( $\alpha=$ $0,05)$ kombinasi perlakuan terbaik kadar Vitamin $\mathrm{C}$ yang diperoleh dari fermentasi apel $5 \mathrm{~kg}$ ditambah ekstrak sari wortel 2,5 $\mathrm{kg}$ setelah proses tahap $2(\mathrm{P} 4)$ sebesar 4,05 
$\mathrm{mg} / 100 \mathrm{ml}$ dan sangat berbeda nyata dengan yang lain. Grafik rerata kadar Vitamin C pada berbagai kombinasi perlakuan antara fermentasi cuka apel dengan tambahan wortel diperlihatkan pada Gambar 5.

Tabel 5. Kadar Vitamin C (mg/100 ml)

Fermentasi apel $5 \mathrm{~kg}$ tanpa wortel (kontrol) (P1)

$2,37 \mathrm{a}$

Fermentasi apel $5 \mathrm{~kg}$ dan wortel 2,5 $\mathrm{kg}$ (diblender bersama) (P2)

Fermentasi apel $5 \mathrm{~kg}$ ditambah ekstrak sari wortel 2,5 $\mathrm{kg}$ setelah proses tahap 1 (P3)

Fermentasi apel $5 \mathrm{~kg}$ ditambah ekstrak sari wortel 2,5 $\mathrm{kg}$ setelah proses tahap 2 (P4)

Keterangan : Angka rerata yang diikuti dengan huruf yang sama pada kolom yang sama tidak berbeda nyata pada uji BNT 5\%

Gambar 5 memperlihatkan bahwa kadar Vitamin C tertinggi diperoleh pada

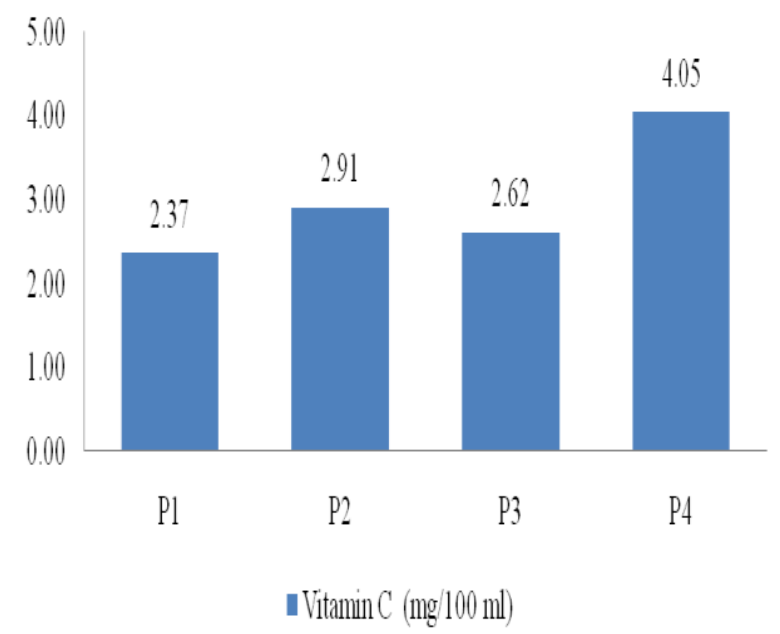

Gambar 5. Grafik kadar Vitamin C (mg/100 ml)

kombinasi perlakuan fermentasi apel $5 \mathrm{~kg}$ ditambah ekstrak sari wortel $2,5 \mathrm{~kg}$ setelah proses tahap 1 (P3) sebesar 90,63 mg/100 $\mathrm{ml}$ dan terendah pada fermentasi apel $5 \mathrm{~kg}$ tanpa wortel (kontrol) (P1) sebesar 136,6 $\mathrm{mg} / 100 \mathrm{ml}$.

\section{Perlakuan Terbaik Parameter Kimia}

Pemilihan perlakuan terbaik parameter kimia (antioksidan dan total fenolik) pada kombinasi perlakuan fermentasi cuka apel dengan tambahan wortel yang berbeda diperlihatkan pada Tabel 6.

Tabel 6. Perlakuan Terbaik

\begin{tabular}{lcccccc}
\hline \multicolumn{1}{c}{ Kombinasi Perlakuan } & $\begin{array}{c}\text { Alkohol } \\
(\%)\end{array}$ & $\begin{array}{c}\text { Total asam } \\
(\%)\end{array}$ & $\begin{array}{c}\text { Gula } \\
\text { reduksi } \\
(\%)\end{array}$ & $\begin{array}{c}\text { Vitamin A } \\
(\mathrm{SI} / 100 \mathrm{ml})\end{array}$ & $\begin{array}{c}\text { Vitamin C } \\
(\mathrm{mg} / 100 \\
\mathrm{ml})\end{array}$ & $\begin{array}{c}\text { Nilai } \\
\text { Produk }\end{array}$ \\
\hline $\begin{array}{l}\text { Fermentasi apel 5 kg tanpa } \\
\text { wortel (kontrol) }(\mathrm{P} 1)\end{array}$ & 2 & 11,30 & 5,47 & 90,63 & 2,37 & 0,000 \\
$\begin{array}{l}\text { Fermentasi apel 5 kg dan } \\
\text { wortel 2,5 kg (diblender } \\
\text { bersama) (P2) }\end{array}$ & 2,16 & 16,44 & 6,19 & 114,51 & 2,91 & 0,339 \\
$\begin{array}{l}\text { Fermentasi apel 5 kg } \\
\text { ditambah ekstrak sari wortel }\end{array}$ & 2,74 & 20,36 & 6,78 & 127,46 & 2,62 & 0,616 \\
$\begin{array}{l}2,5 \mathrm{~kg} \text { setelah proses tahap } \\
\begin{array}{l}\text { (P3) } \\
\text { Fermentasi apel 5 kg } \\
\text { ditambah ekstrak sari wortel }\end{array}\end{array}$ & 2,52 & 24,36 & 7,80 & 136,60 & & \\
$\begin{array}{l}2,5 \mathrm{~kg} \text { setelah proses tahap } \\
\text { (P4) }\end{array}$ & & & & & & \\
\hline
\end{tabular}


Tabel 6 memperlihatkan kombinasi per-lakuan terbaik kimia berdasarkan kadar alkohol, total asam, gula reduksi, vitamin A, dan vitamin $\mathrm{C}$ didapatkan fermentasi apel 5 $\mathrm{kg}$ ditambah ekstrak sari wortel $2,5 \mathrm{~kg}$ setelah proses tahap 2 dengan karakteristik sebagai berikut : kadar alkohol atau etanol sebesar 2,52\%, total asam sebesar 24,36\%, kadar gula reduksi sebesar 7,80\%, vitamin A sebesar 136,6 Si/100 ml, dan vitamin C sebesar 2,62 mg/100 ml

\section{KESIMPULAN}

Kombinasi perlakuan terbaik pada parameter kimia diperoleh dari kombinasi perlakuan fermentasi apel $5 \mathrm{~kg}$ ditambah ekstrak sari wortel $2,5 \mathrm{~kg}$ setelah proses tahap 2 dengan kadar alkohol atau etanol sebesar 2,52\%, total asam sebesar 24,36\%, kadar gula reduksi sebesar 7,80\%, vitamin A sebesar 136,6 Si/100 ml, dan vitamin C sebesar 2,62 mg/100 ml.

\section{DAFTAR PUSTAKA}

Anonymous. $\left(2016^{\mathrm{a}}{ }^{2}\right.$ Apel. https://id.wikipedia.org/wiki/Apel. diakses tanggal 14 April 2016.

Arscott, S.A. and Tanumihardjo, S.A. (2010). Carrots of many colors provide basic nutrition and bioavailable phytochemicals acting as a functional food. Compr Rev Food Sci F. 9: 223-239.

Bowman, M. J. and Simon, P. W. (2013). Quantification of the relative abundance of plastome to nuclear genome in leaf and root tissues of carrot (Daucus carota L.) using quantitative PCR. Plant Molecular Biology Reporter 31(4):1040-1047.

Grune, T, Lietz, G., Palou, A., Ross, A.C., Stahl, W., Tang, G., Thurnjam, D., Yin Shi-an, and Biesalski, H.K. (2010). $\beta$-carotene is an important vitamin A source for humans. J Nutr 140: 12 S-I.

Hlebowicz, J., Darwiche, G., Björgell, O. and Almér, L.O. (2007). Effect of
Apple Cider Vinegar on Delayed Gastric Emptying in Patients with Type 1 Diabetes Mellitus: A Pilot Study. BMC Gastroenterology, 7 (46): 1-6.

Kaushal, B.B.L. and Sharman, P.C. (1995). Apple Juice at Hand Book of Fruit Science and Technology, Production, Composition, Storage and Processing. Edited by D.K. saluke and SS. Kadam. Marcel dekker. Inc. New York.

Mech-Nowak, A., Swiderski, A., Kruczek, M., Luczak, I., and Kostecka-Gugala, A. (2012). Content of carotenoids in roots of seventeen cultivars of Daucus carota L. Acta Biochimica Polonica 59(1): 139.

Rukmana, R. (1995). Bertanam wortel. Kanisius. Yogyakarta.

Salunkhe. (1991). Storage, Processing and Nutritional Quality of Fruit and Vegetables. Vol 1.2 ${ }^{\text {nd }}$ ed. CRC Press. Boca Raton. Finlandia.

Wibowo, D. (1990). Teknologi Fermentasi. PAU Pangan dan Gizi, Universitas Gadjah Mada. Yogyakarta.

Wijayakusuma, H. (2000). Potensi Obat Asli Indonesia sebagai Produk Kesehatan. Risalah Pertemuan Ilmiah Penelilian dan Pengembangan Teknologi Isolop dan Radiasi. http://digilib.batan.go.id/eprosiding/File\%20Prosiding/Kesehata n/Risalah \%202000/2000/HembingWijaya.pdf. Diakses tanggal: 4 Agustus 2014.

Winarti, C. dan Nurdjanah, N. (2005). Peluang Tanaman Rempah dan Obat sebagai Sumber Pangan Fungsional. Jurnal Litbang Pertanian, 24 (2):4755.

Woro, H.S., Mubarak, A.S., Mukti, A.T., dan Ninin, C. (2009). Penambahan wortel sebagai sumber beta karoten alami dengan beberapa metode pengolahan pada pakan terhadap peningkatan warna biru lobster red claw. Jurnal Akuakultur Indonesia 8(1):19-27. 